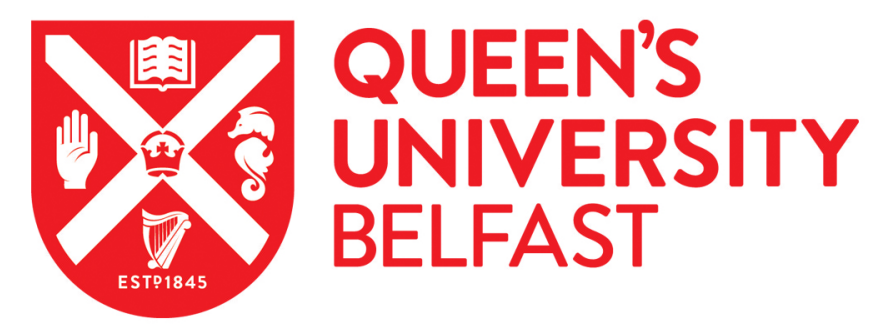

\title{
Microplasma assisted synthesis of gold nanoparticle/graphene oxide nanocomposites and their potential application in SERS sensing
}

Sun, D., Tang, M., Zhang, L., Falzon, B. G., Padmanaban, D. B., Mariotti , D., Maguire , P., Xu, H., Chen, M., \& Sun, D. (2019). Microplasma assisted synthesis of gold nanoparticle/graphene oxide nanocomposites and their potential application in SERS sensing. Nanotechnology, 30, [455603]. https://doi.org/10.1088/1361-6528/ab2a23

Published in:

Nanotechnology

Document Version:

Peer reviewed version

Queen's University Belfast - Research Portal:

Link to publication record in Queen's University Belfast Research Portal

Publisher rights

Copyright 2019 IOP. This work is made available online in accordance with the publisher's policies. Please refer to any applicable terms of use of the publisher.

\section{General rights}

Copyright for the publications made accessible via the Queen's University Belfast Research Portal is retained by the author(s) and / or other copyright owners and it is a condition of accessing these publications that users recognise and abide by the legal requirements associated with these rights.

Take down policy

The Research Portal is Queen's institutional repository that provides access to Queen's research output. Every effort has been made to ensure that content in the Research Portal does not infringe any person's rights, or applicable UK laws. If you discover content in the Research Portal that you believe breaches copyright or violates any law, please contact openaccess@qub.ac.uk. 
ACCEPTED MANUSCRIPT

\section{Microplasma assisted synthesis of gold nanoparticle/graphene oxide nanocomposites and their potential application in SERS sensing}

To cite this article before publication: Daye Sun et al 2019 Nanotechnology in press https://doi.org/10.1088/1361-6528/ab2a23

\section{Manuscript version: Accepted Manuscript}

Accepted Manuscript is "the version of the article accepted for publication including all changes made as a result of the peer review process, and which may also include the addition to the article by IOP Publishing of a header, an article ID, a cover sheet and/or an 'Accepted

Manuscript' watermark, but excluding any other editing, typesetting or other changes made by IOP Publishing and/or its licensors"

This Accepted Manuscript is @ 2019 IOP Publishing Ltd.

During the embargo period (the 12 month period from the publication of the Version of Record of this article), the Accepted Manuscript is fully protected by copyright and cannot be reused or reposted elsewhere.

As the Version of Record of this article is going to be / has been published on a subscription basis, this Accepted Manuscript is available for reuse under a CC BY-NC-ND 3.0 licence after the 12 month embargo period.

After the embargo period, everyone is permitted to use copy and redistribute this article for non-commercial purposes only, provided that they adhere to all the terms of the licence https://creativecommons.org/licences/by-nc-nd/3.0

Although reasonable endeavours have been taken to obtain all necessary permissions from third parties to include their copyrighted content within this article, their full citation and copyright line may not be present in this Accepted Manuscript version. Before using any content from this article, please refer to the Version of Record on IOPscience once published for full citation and copyright details, as permissions will likely be required. All third party content is fully copyright protected, unless specifically stated otherwise in the figure caption in the Version of Record.

View the article online for updates and enhancements. 


\section{Microplasma assisted synthesis of gold nanoparticle/graphene oxide nanocomposites and their potential application in SERS sensing}

Daye Sun ${ }^{1}$, Miao Tang. ${ }^{2}$, Li Zhang ${ }^{3}$, Brian G. Falzon. ${ }^{1}$, Dilli Babu Padmanaban ${ }^{4}$, Davide Mariotte $^{4}$, Paul Maguire ${ }^{4}$, Heping $\mathrm{Xu}^{2}$, Mei Chen ${ }^{2}$, Dan Sun*1

${ }^{1}$ Advanced Composites Research Group (ACRG), School of Mechanical and Aerospace Engineering, Queen's University, Belfast BT9 5AH, U.K.

${ }^{2}$ The Wellcome-Wolfson Institute of Experimental Medicine, School of Medicine, Dentistry and Biomedical Sciences, Queen's University Belfast BT9 7BL, U.K.

${ }^{3}$ Research Center for Nano-Biomaterials, Analytical \& Testing Center, Sichuan University, Chengdu 610065, China

${ }^{4}$ Nanotechnology and Integrated Bioengineering Centre, Ulster University, Co Antrim BT37 OQB, U.K.

*Corresponding author : Dr. Dan Sun; email: d.sun @qub.ac.uk

\section{Abstract}

This is the first study on the deployment of direct current (DC) atmospheric pressure microplasma (APM) technique for the single step synthesis of gold nanoparticle/graphene oxide (AuNP/GO) nanocomposites. The nanocomposites were characterized using ultraviolet-visible spectroscopy (UVVis), X-ray diffraction (XRD) and X-ray photoelectron spectroscopy (XPS) and their formation mechanisms have been discussed in detail. Our AuNP/GO nanocomposites are highly biocompatible and have demonstrated surface enhanced Raman scattering (SERS) properties as compared to pure AuNPs and pure GO. Their potential as SERS substrate has been further demonstrated using probe molecules (methylene blue) at different concentrations.

\section{Introduction}

Atmospheric pressure microplasma (APM) operates at room temperature under non-thermal equilibrium conditions with high electron temperature (e.g. $\left.10^{4} \mathrm{~K}\right)[1,2]$. When in contact with aqueous solution, APM can lead to dynamic production of highly reactive species including solvated electrons, radicals (e.g. $\mathrm{OH}^{*}, \mathrm{H}^{*}$, and $\mathrm{O}^{*}$, etc.), ions (e.g. $\mathrm{OH}^{-}$and $\mathrm{H}^{+}$), and $\mathrm{H}_{2} \mathrm{O}_{2}[3,4]$. These species can interact with metal salt precursors within the aqueous solution via different reaction pathways, initiating the reduction of metal ions [5-7]. As a result, APM-liquid interaction has become an emerging technology for the synthesis of various metal based nanoparticles (NPs) such as $\mathrm{AgNPs}, \mathrm{AuNPs}, \mathrm{Cu}_{2} \mathrm{O} \mathrm{NPs}, \mathrm{Co}_{3} \mathrm{O}_{4}$, $\mathrm{Fe}_{3} \mathrm{O}_{4} \mathrm{NPs}$, and alloyed $\mathrm{Au}_{\mathrm{x}} \mathrm{Ag}_{1-\mathrm{x}} \mathrm{NPs}$ [6-12]. The unique advantage of the APM synthetic approach is its ability to create highly charged NP surfaces within minutes and enable the stabilisation of NPs in aqueous based solutions without the need for surfactants or ligand coating.

In recent years, APM based nanomaterials synthesis has been expanded further towards the fabrication of nanocomposite systems. By exposing aqueous mixture of metal salt precursors and polymers to high doses of plasma induced reactive species, we have successfully achieved one-step synthesis of a number 
of multifunctional nanocomposites such as AuNP/PEDOT: PSS for potential fuel cell electro-catalyst, thermos-responsive $\mathrm{Fe}_{3} \mathrm{O}_{4}$ /poly (N-isopropylacrylamde), and $\mathrm{AuAg} \mathrm{NP} / \mathrm{PVA}$ hydrogel nanocomposites for potential bioapplications[13-15]. We have also developed the rapid and green APM synthesis process for the fabrication of AuNP decorated carbon nanotubes with enhanced photothermal conversion capability[16]. These preliminary results highlight the exciting possibility of using APM to synthesize a wide range of advanced nanocomposites for functional applications.

Graphene oxide (GO), one of the graphene derivatives, is a two-dimensional (2D) sheet with a $\mathrm{sp}^{2}-$ hybridized carbon atoms packed into a honeycomb lattice[17]. While retaining the unique structure and excellent mechanical properties of graphene, GO is rich in surface functional groups (e.g. -OH, -C-Oand $-\mathrm{COOH}$ ), which promote the cell adhesion and biocompatibility[18,19]. Functional metallic NPs, in particular gold NPs (AuNPs), when incorporated into GO, can form multifunctional nanocomposites for many applications such as drug delivery, tissue engineering, electrocatalysis[20-22]. AuNP/GO nanocomposites are also of particular interest for surface enhanced Raman scattering (SERS) sensing[23]. In SERS sensing, AuNPs with localized surface plasmon resonance (LSPR) property could lead to a much higher Raman signal enhancement through the electromagnetic mechanism (EM)[24]. GO on the other hand, can offer enhanced Raman signal through a chemical mechanism (CM) due to the electron transfer between the analyte and the graphene structures[25]. AuNPs/GO nanocomposites can fully deploy both mechanisms, leading to a much enhanced SERS capability[26]. To date, AuNP/GO nanocomposites with SERS activities have been reported in a number of SERS related applications, such as detection of aromatic molecules and biomolecules, intercellular imaging, and cancer diagnostics[20,27-32]. Some of the synthetic routes of AuNP/GO nanocomposites reported for SERS based applications have been summarized in Table 1. Although traditional wet chemistry based synthesis techniques (e.g. in situ chemical reduction,[30,33,34] self-assembling,[31,35-38] and electrochemical deposition.[39]) have been commonly used, most of these approaches require elevated temperatures, long processing time (hours), and / or multiple reaction steps / cleansing procedures. Photo-reduction process has also been reported for the synthesis of AuNP/rGO[40], however, the long exposure to UV-irradiation may be potentially hazardous to human[41].

In this work, we demonstrated the first use of a direct current (DC) APM for the one-step synthesis of AuNP/GO nanocomposites. An in-depth understanding has been developed into the interfacial interactions between AuNP and GO during the APM assisted synthesis process and the formation mechanism of AuNP/GO nanocomposites under the plasma induced chemistry has been elucidated in detail. The resulting AuNP/GO nanocomposites have been evaluated for their biocompatibility and their potential as SERS substrate has been demonstrated using a model probe molecule methylene blue (MB). 
Table 1. Au-graphene nanocomposites with enhanced SERS for biomolecule detection applications.

\begin{tabular}{|c|c|c|c|c|c|c|c|}
\hline Method & Platform & $\begin{array}{c}\text { Specified } \\
\text { AuNP shapes } \\
\end{array}$ & Interlayers & Reducing Agent & Probe molecules & Applications & Ref \\
\hline \multirow{3}{*}{$\begin{array}{l}\text { In situ chemical } \\
\text { reduction }\end{array}$} & AuNP/GO & Spheres & N/A & Tyrosine & $\begin{array}{c}\text { Malachite Green } \\
\text { (MG) }\end{array}$ & SERS & [30] \\
\hline & AuNP/rGO & N/A & Polyvinylpyrrolidone & Ascorbic Acid & NBA & SERS & [33] \\
\hline & $\begin{array}{l}\text { AuNP/GO } \\
\text { AuNP/rGO }\end{array}$ & & N/A & Sodium Citrate & Rhodamine 6G (R6G) & SERS & [34] \\
\hline \multirow{4}{*}{ Self-assembling } & & & Polyvinylpyrrolidone & $\begin{array}{c}\text { Sodium } \\
\text { Borohydride }\end{array}$ & $\begin{array}{l}\text { Crystal Violet (CV), } \\
\text { Neutral Red (NR), } \\
\text { Trypan Blue (TB) and } \\
\text { Ponceau S (PS) }\end{array}$ & SERS & [31] \\
\hline & & N/A & 2-Mercaptopyridine & $\begin{array}{c}\text { Sodium } \\
\text { Borohydride }\end{array}$ & Rh6G & SERS & [36] \\
\hline & & Popcorns & $\begin{array}{c}\text { Thionyl Chloride and } \\
\text { Cysteamine }\end{array}$ & $\begin{array}{l}\text { Sodium Citrate } \\
\text { and } \\
\text { Sodium } \\
\text { Borohydride }\end{array}$ & $\begin{array}{l}\text { Rh6G, HIV DNA, and } \\
\text { Methicillin Resistant } \\
\text { Staphylococcus } \\
\text { Aureus (MRSA) } \\
\text { bacteria } \\
\end{array}$ & SERS & [38] \\
\hline & $\begin{array}{l}\text { AuNP/GO } \\
\text { AuNP/rGO }\end{array}$ & N/A & 2-Mercaptopyridine & Sodium Citrate & $\begin{array}{l}\text { P-aminothiophenol } \\
\text { (PATP) }\end{array}$ & SERS and Catalysis & [37] \\
\hline Electrochemical & AuNP/rGO & N/A & N/A & N/A & Rhodamine B (RhB) & SERS & [39] \\
\hline UV-irradiation & AuNP/GO & N/A & N/A & N/A & $\begin{array}{l}\text { Crystal Violet (CV) } \\
\text { and Flavin } \\
\text { Adenine Dinucleotide } \\
\text { (FAD) }\end{array}$ & $\begin{array}{l}\text { SERS and } \\
\text { Electrochemical } \\
\text { reactions }\end{array}$ & [40] \\
\hline
\end{tabular}




\section{Experiment section}

2 APM set-up. The APM set-up deployed in this study is shown in Schematic 1. The cathode consists of 3 a hollow stainless-steel capillary with an inner diameter of $250 \mu \mathrm{m}$, and the anode is a conductive carbon 4 rod which is immersed in the solution. The two electrodes were vertically placed with a distance of $5 \quad 2 \mathrm{~cm}$ in between. The capillary is placed $\sim 1 \mathrm{~mm}$ above the liquid surface, through which helium (He) 6 gas was supplied (25 SCCM). The plasma can be ignited at $\sim 2 \mathrm{kV}$ and all samples were treated at a 7 constant current of $5 \mathrm{~mA}$ for $10 \mathrm{~min}$ without stirring the solutions.

8 The preparation of AuNP/GO nanocomposites. GO aqueous solution (Graphene Laboratories Inc., $950 \mathrm{mg} / \mathrm{mL}$ ) was mixed with $\mathrm{HAuCl}_{4}$ (Sigma-Aldrich) aqueous solution to obtained aqueous $10 \mathrm{HAuCl}_{4} / \mathrm{GO}$ mixtures with constant $\mathrm{GO}$ concentration $(0.5 \mathrm{mg} / \mathrm{mL})$ and varying $\mathrm{HAuCl}_{4}$ concentrations $11(2.5 \mu \mathrm{M}, 0.1 \mathrm{mM}$, and $0.2 \mathrm{mM})$. The resulting mixtures were settled for $10 \mathrm{~min}$ before APM treatment. 12 The samples after APM treatment were named as $2.5 \mu \mathrm{M}$ AuNP/GO, $0.1 \mathrm{mM}$ AuNP/GO, and $0.2 \mathrm{mM}$ 13 AuNP/GO, respectively. All samples were collected and stored in glass vials for further analysis (see 14 Figure $\mathrm{S} 1$ in supporting information).

15 Characterization. The optical properties of the samples were analyzed using ultraviolet-visible (UV16 Vis) spectroscopy (Cary 60 UV-Vis, Agilent Technologies). Transmission electron microscopy (TEM) 17 analysis was carried out using a Philips Tecnai F20D transmission electron microscope, and size of the 18 AuNPs within the nanocomposite was obtained by analyzing 150 NPs using "ImageJ" software. The 19 diameter was measured for spherical NPs, while for NPs with other morphologies, the longest dimension was measured. X-ray powder diffraction (XRD) patterns of the samples were carried out using a PAN-alytical X'PERT Pro MPD machine, while the XRD pattern were referred to the JCPDS card. X-ray photoelectron spectroscopy (XPS) was conducted using Kratos Axis Ultra XPS system (monochromatic $\mathrm{Al} \mathrm{K \alpha} \mathrm{X}$-rays, $1486 \mathrm{eV}$ ) at $10 \mathrm{~mA}$ current, $15 \mathrm{kV}$ voltage under $1 \times 10^{-9} \mathrm{mbar}$ of pressure. The XPS samples were prepared by drop-casting aqueous sample solutions on intrinsic silicon wafer, followed by drying thoroughly under room temperature. High-resolution XPS spectra $(0.05 \mathrm{eV})$ including $\mathrm{C} 1 \mathrm{~s}$ and $\mathrm{Au} 4 \mathrm{f}$ peaks of all samples were performed under a pass energy of $40 \mathrm{eV}$. The spectra

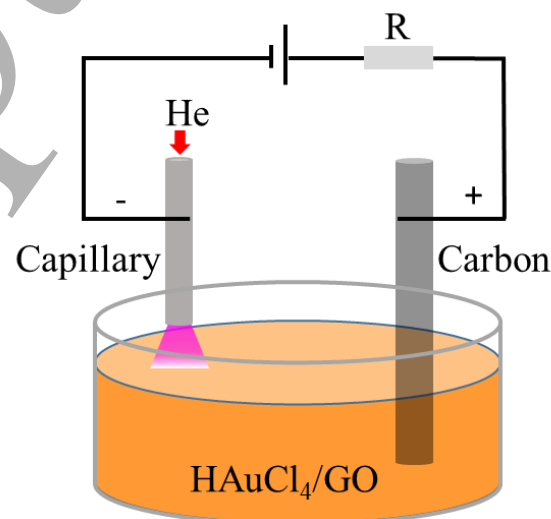

Scheme 1. APM set-up used in the present work. 
were calibrated and normalized to the $\mathrm{C} 1 \mathrm{~s}$ peak located at $284.5 \mathrm{eV}$ and the data were analyzed using an open source software CasaXPS. Samples for Raman test was prepared by drop-casting $100 \mu \mathrm{L}$ of each AuNP/GO aqueous solution on neat silicon wafer with a pre-fabricated $6 \mathrm{~mm} \times 6 \mathrm{~mm}$ well followed by drying under room temperature. Raman spectroscopy were performed using a $632 \mathrm{~nm} \mathrm{~N}_{2-}$ $\mathrm{H}_{2}$ laser excitation Raman spectroscopy (LabRAM 300, Horiba, UK with a 632 nm source). The operating current and voltage of the laser is $7 \mathrm{~mA}$ and $3.7 \mathrm{kV}$, respectively. For all samples, a $1 \%$ filter of the output power $(0.259 \mathrm{~W})$ was chosen to avoid the surface damages of the materials. Measurements were repeated three times to ensure reproducibility.

SERS measurements. $0.1 \mathrm{mM}$ AuNP/GO was selected as a typical sample to evaluate the potential of our nanocomposites for SERS sensing applications. MB was used as model probe molecule. $1 \mathrm{~mL}$ of the $0.1 \mathrm{mM}$ AuNP/GO aqueous solution was mixed with $1 \mathrm{~mL} \mathrm{MB}$ of varying concentrations $\left(2 \times 10^{-1}\right.$ $\mathrm{mg} / \mathrm{mL}, 2 \times 10^{-2} \mathrm{mg} / \mathrm{mL}, 2 \times 10^{-3} \mathrm{mg} / \mathrm{mL}$, and $\left.2 \times 10^{-4} \mathrm{mg} / \mathrm{mL}\right)$, and the mixtures were settled for $30 \mathrm{mins}$ to allow thorough adsorption of the molecules. $100 \mu \mathrm{L}$ of each sample was drop-casted onto silicon wafer with a pre-fabricated $6 \mathrm{~mm} \times 6 \mathrm{~mm}$ well and dried thoroughly under ambient condition before conducting Raman scanning.

In vitro cytotoxicity test. The alamarBlue ${ }^{\mathrm{TM}}$ Cell Viability Reagent (ThermoFisher Scientific Inc., Gaithersburg, MD, USA) was used to determine the cytotoxicity of nanocomposites following the manufacturer's instruction. Immortalized human cervical cells, HeLa cells (ATCC® CCL-2TM, Manassas, VA, USA) were cultured in Minimum Essential Medium (MEM, ThermoFisher Scientific Inc.) supplemented with $3.9 \mathrm{mM}$ L-glutamine, $1.0 \mathrm{mM}$ sodium pyruvate, $2.2 \mathrm{~g} / \mathrm{L}$ sodium bicarbonate and $10 \%$ fetal bovine serum (FBS) and maintained in a humidified atmosphere containing $5 \% \mathrm{CO}_{2}$ at $37^{\circ} \mathrm{C}$. HeLa cells were cultured until they reached approximately $80 \%$ confluency before preparing the plates for the cytotoxicity assay. Cells were seeded into Costar® 96-well assay plates (Costar 3904, Corning Inc., NY, USA) with different initial cell densities of $5 \times 10^{3}, 4 \times 10^{3}$ and $3 \times 10^{3}$ cells per well. The cells were cultured for $24 \mathrm{~h}$ to allow attachment to the wells. $100 \mu \mathrm{L}$ water suspension of tested materials, $0.1 \mathrm{mM}$ AuNP, GO, or $0.1 \mathrm{mM}$ AuNP/GO was mixed with $100 \mu \mathrm{L} 2 \mathrm{X}$ MEM supplemented with 10\% FBS and 1\% Primocin (ThermoFisher Scientific Inc.). For each well, the cultured medium was replaced with $200 \mu \mathrm{L}$ complete medium of tested materials. Cells were maintained in $37^{\circ} \mathrm{C}$ incubator for $24 \mathrm{~h}, 48 \mathrm{~h}$ and $72 \mathrm{~h}$, corresponding to the initial cell density of $5 \times 10^{3}, 4 \times 10^{3}, 3 \times 10^{3}$ cells per well, respectively. $100 \mu \mathrm{L}$ of autoclaved double-distilled water was used as no treatment control. After each time point, cells were washed twice with PBS. Complete medium containing $10 \%$ alamarBlue $^{\circledR}$ solution was added and incubated in the $37^{\circ} \mathrm{C}$ incubator for $2 \mathrm{~h}$. After incubation, fluorescence was measured using a POLARstar ${ }^{\circledR}$ Glomax multidetection system (Promega, Southampton, UK) with excitation/emission wavelength at 544/590 nm. Cell viability was calculated by the relative ratio of fluorescence from test materials to control media. 


\section{$1 \quad$ Results and discussion}

$2 \mathrm{HAuCl}_{4} / \mathrm{GO}$ mixtures showed immediate colour change when the samples were subjected to APM 3 treatment (See Figure S1 in supporting information). The optical properties of the APM treated samples 4 are shown in Figure 1. It can be seen that the UV-vis absorption spectrum of GO is insensitive to the 5 APM treatment. However, in the presence of $\mathrm{HAuCl}_{4}$, the UV-vis spectra of APM treated $0.1 \mathrm{mM}$ $6 \mathrm{HAuCl}_{4} / \mathrm{GO}(0.1 \mathrm{mM} \mathrm{AuNP} / \mathrm{GO})$ and $0.2 \mathrm{mM} \mathrm{HAuCl} / \mathrm{GO}(0.2 \mathrm{mM} \mathrm{AuNP} / \mathrm{GO})$ mixtures both display 7 a surface plasmon resonance (SPR) band typical of AuNPs (539 nm and $553 \mathrm{~nm}$, respectively). The 8 SPR peak wavelength is red shifted with increasing initial $\mathrm{HAuCl}_{4}$ concentration (from $0.1 \mathrm{mM}$ to 0.2 $9 \mathrm{mM})$. This can be attributed to the larger AuNPs formed within samples containing higher $\mathrm{HAuCl}_{4}$ 10 concentration[42].

11 The presence of AuNP on GO was further confirmed by TEM analysis, see Figure 2. Figure 2A shows 12 a typical TEM image of GO sheets. AuNPs were found to be well dispersed on the surfaces of GO for 13 the plasma treated samples, see Figure 2B-D. It can be seen that AuNPs are present in the $2.5 \mu \mathrm{M}$ 14 AuNP/GO sample, although no AuNP SPR band has been observed in its associated UV-vis spectrum 15 in Fig 1. This may be due to the number of NPs formed under very low initial $\mathrm{HAuCl}_{4}$ is below the UV16 vis detection limit[16]. The average NP size increased from $19.2 \pm 7.3 \mathrm{~nm}$ to $63.4 \pm 4.3 \mathrm{~nm}$ with increasing $\mathrm{HAuCl}_{4}$ precursor concentration (Figure 2B-D insets). This is consistent with the red shift of the SPR peak shown in UV-Vis absorption spectra in Figure, 1. It is noteworthy that the AuNPs within the $2.5 \mu \mathrm{M}$ AuNP/GO sample feature clusters of coalesced NPs with much smaller sizes (see also Figure $\mathrm{S} 2$ in supporting information), in contrast to the well dispersed single AuNPs in $0.1 \mathrm{mM}$ and $0.2 \mathrm{mM}$ AuNP/GO samples.

22 It is also of interest to investigate if the GO within the nanocomposite structure has undergone any 23 reduction reaction (e.g. formation of reduced $\mathrm{GO}$ ) during the APM treatment. Figure 3 shows the XRD spectra of pure GO and APM treated GO. For pure GO, the crystalline peaks at $2 \theta=9.77^{\circ}$ and $2 \theta=$ $23.60^{\circ}$ signify the (001) and (002) crystalline structures of GO, respectively[43]. After the APM treatment, the intensity of (001) peak was significantly reduced, indicating the reduction of oxygen-

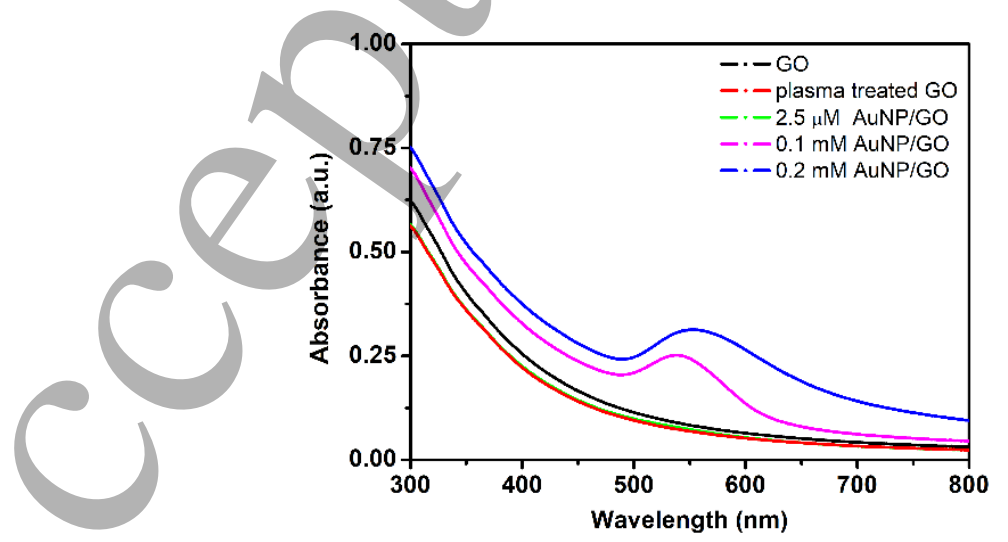

Figure 1. The UV-Vis spectra of GO, APM treated GO and AuNP/GO nanocomposites 


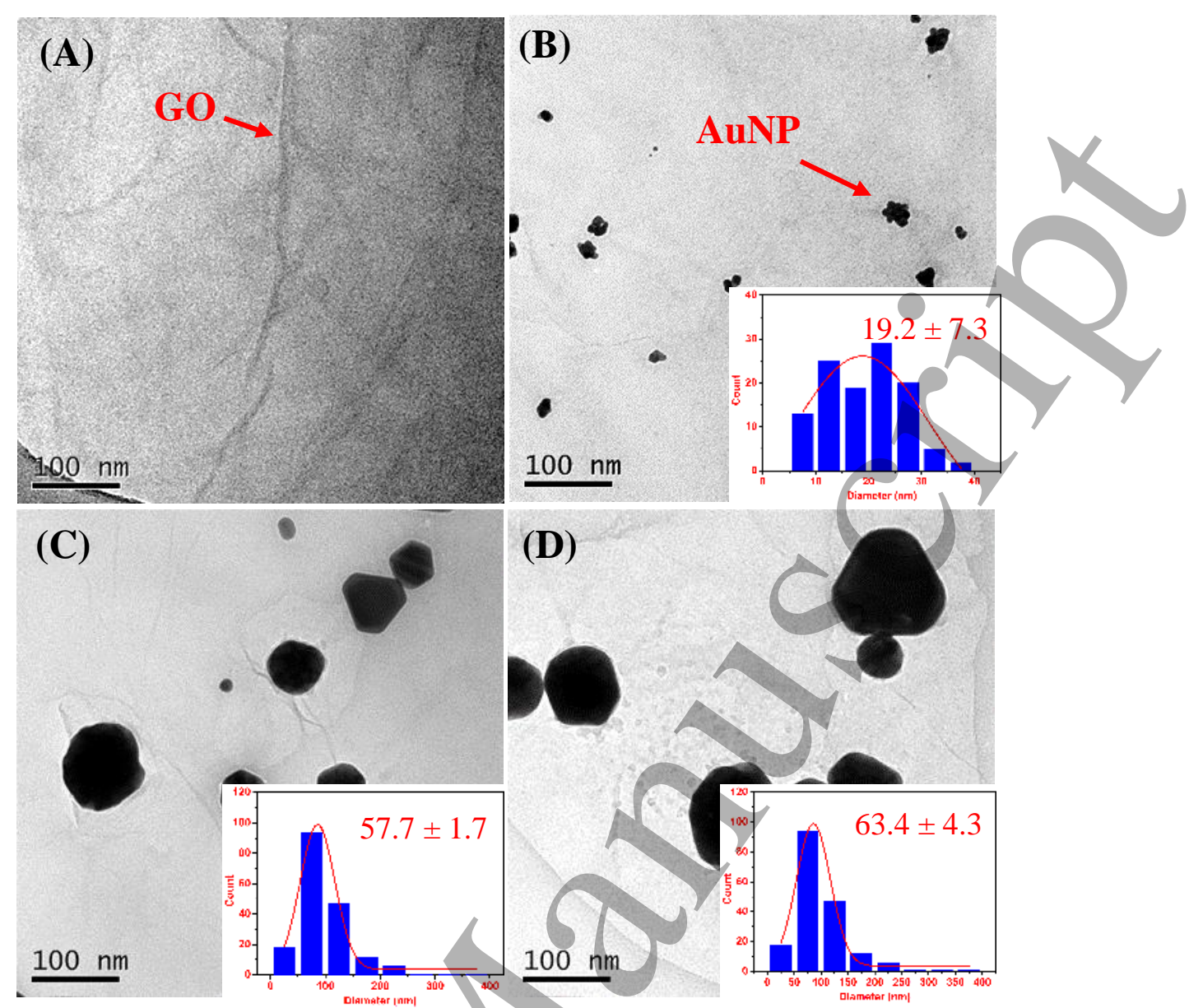

Figure 2. TEM micrographs of (a) GO, (b) $2.5 \mu \mathrm{M}$ AuNP/GO, (c) $0.1 \mathrm{mM} \mathrm{AuNP/GO}$, and (d) $0.2 \mathrm{mM}$ AuNP/GO; (b)-(d) insets: size distribution of AuNPs within each sample.

1 containing functionalities on GO[44]. This suggests the APM treatment has caused reduction of GO in 2 aqueous mixtures containing $\mathrm{HAuCl}_{4}$. The finding is consistent with the previous study where GO was

3 AMP treated in water only[2]. For AuNP/GO samples, the (001) peak of GO can still be observed in 4 the XRD spectra. Comparing to the pure GO, the intensity of this peak also decreased, but to a lesser 5 extent. Additionally, new peak at $2 \theta=38.2^{\circ}$ emerges, which correspond to the (111) facet of the face 6 cornered cubic (fcc) gold nanostructures.[45] These results indicate that both Au ions and the GO 7 surface oxygen-functionalities have undergone reduction reaction during the APM process. There could 8 be a competition between these two reduction processes, hence a lower degree of GO reduction is 9 expected for the AuNP/GO sample (less reduced (001) GO peak intensity). With increasing initial $10 \mathrm{HAuCl}_{4}$ concentration, the intensity of the $2 \theta=38.2^{\circ}$ peak significantly increases, suggesting that (111) 11 facet is the predominant AuNP growth orientation under the APM treatment[45]. The preferential 12 growth of AuNPs along the (111) facet with increasing $\mathrm{HAuCl}_{4}$ concentration suggest the crystal grown 13 in these samples is dominated by the non-equilibrium kinetic growth regime[46,47].

14 Figure 4A presents the survey XPS of pure GO and 0.1 mM AuNP/GO. In contrast to pure GO, a distinct $15 \mathrm{Au} 4 \mathrm{f}$ peak at binding energy (BE) around $83 \mathrm{eV}$ (Figure S3 in supporting information) can be found 16 in the $0.1 \mathrm{mM}$ AuNP/GO spectrum. The formation of AuNPs on the surface of GO resulted in a slightly 


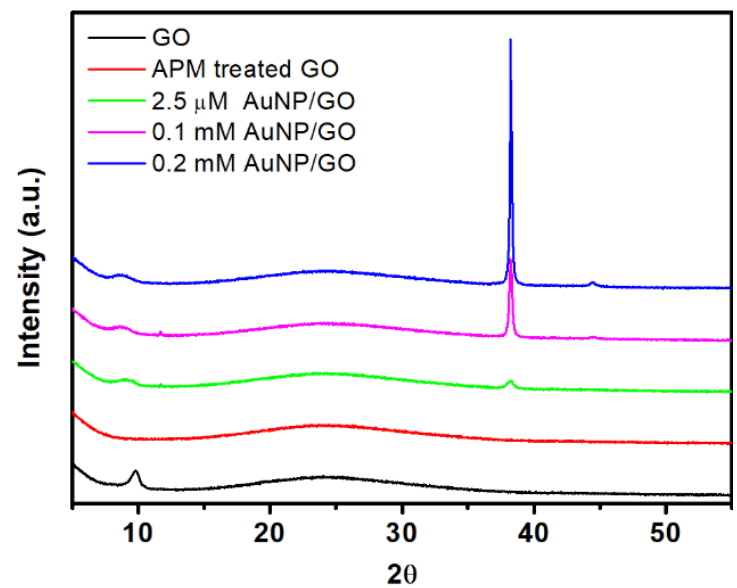

Figure 3. XRD spectra of pure GO, APM treated GO and AuNP/GO nanocomposites.

1 increased $\mathrm{C} / \mathrm{O}$ ratio in the survey spectra (from 1.83 for pure GO to 1.87 for $0.1 \mathrm{mM} \mathrm{AuNP/GO}$ ). In 2 order to develop more in-depth understanding of the AuNP-GO interfacial interaction, high-resolution 3 XPS spectra of the $\mathrm{C} 1 \mathrm{~s}$ and $\mathrm{Au} 4 \mathrm{f}$ core peaks were further analysed for pure $\mathrm{GO}, 0.1 \mathrm{mM} \mathrm{HAuCl} / 4 / \mathrm{GO}$ 4 aqueous mixture, and $0.1 \mathrm{mM}$ AuNP/GO nanocomposite. As is shown in Figure 4B, the C 1s core 5 region of pure GO consist of three main components: $284.4 \mathrm{eV}$ (C-C), $286.6 \mathrm{eV}(\mathrm{C}-\mathrm{O})$, and 288.0 $6 \mathrm{eV}(\mathrm{C}=\mathrm{O})[48]$; the fraction of each component is listed in Table 2. The $\mathrm{C}$ 1s core peak in $\mathrm{HAuCl}_{4} / \mathrm{GO}$ 7 (Figure 4C) consists of $284.6 \mathrm{eV}(\mathrm{C}-\mathrm{C}), 286.7 \mathrm{eV}$ (C-O), and $288.3 \mathrm{eV}(\mathrm{C}=\mathrm{O})$. Comparing to the $\mathrm{C} 1 \mathrm{~s}$ 8 peak of the pure GO sample, the BE of these signals have slightly shifted, indicating the change of their 9 chemical environments. A possible reason for such change is the formation of $\mathrm{Au}-\mathrm{O}-\mathrm{C}$ bonds, as $10 \mathrm{HAuCl}_{4}$ interacts with the $\mathrm{GO}$ surface oxygen-functionalities[40]. The Au $4 \mathrm{f}$ core peak of the $0.1 \mathrm{mM}$ $11 \mathrm{HAuCl}_{4} / \mathrm{GO}$ mixture (Figure 4D) can be deconvoluted into three doublets. The two doublets centred at $\mathrm{BE}$ of $84.7 / 88.4 \mathrm{eV}$ and $87.0 / 90.7 \mathrm{eV}$ can be correlated to the ionic Au states of the $\mathrm{HAuCl}_{4} \mathrm{salt}, \mathrm{Au}^{1+}$ and $\mathrm{Au}^{3+}$, respectively (Table 2) [49-51]. A third doublet centred at $84.2 / 87.9 \mathrm{eV}$ is also noticed, which signifies $\mathrm{Au}^{0}$ state.[52] This could be due to the reduction of $\mathrm{HAuCl}_{4}$ occurred during the XPS sample drying process, driven by the difference between the reduction potential of $\mathrm{AuCl}_{4}{ }^{-}$and the oxidation potential of GO[53]. Howeyer, this process is usually very slow, especially in the absence of external energy input (such as heating or sonication) [54], and the presence of AuNPs in the $0.1 \mathrm{mM} \mathrm{HAuCl} / \mathrm{GO}$ mixture prior to APM treatment can be considered negligible in comparison to the AuNPs formed during the subsequent synthesis process. Figure $4 \mathrm{E}$ shows that after the APM treatment, the total fraction of oxygen-containing components $(\mathrm{C}-\mathrm{O}$ and $\mathrm{C}=\mathrm{O})$ in the $\mathrm{C} 1 \mathrm{~s}$ core peak of $0.1 \mathrm{mM}$ AuNP/GO decreased from $52.1 \%$ to $44.9 \%$. This reduction can be due to (i) the ability of APM to reduce the oxygen-containing groups of GO, as is supported by the XRD analysis earlier; and (ii) the APM induced AuNP formation on GO surface at the Au-O-C bonding sites. Figure 4F shows the $\mathrm{Au} 4 \mathrm{f}$ spectrum of the $0.1 \mathrm{mM}$ AuNP/GO nanocomposite, where two doublets of the typical $\mathrm{Au}^{1+}$ peaks centred at the $\mathrm{BE}$ of $84.9 / 88.8 \mathrm{eV}$ and the typical $\mathrm{Au}^{0}$ peaks centred at the $\mathrm{BE}$ of $84.0 / 87.7 \mathrm{eV}$, respectively (Table 2). 26 Clearly, comparing to the $\mathrm{Au} 4 \mathrm{f}$ peak of $0.1 \mathrm{mM} \mathrm{HAuCl} / \mathrm{GO}$ sample, the ionic state $\mathrm{Au}$ has gone 
(A)

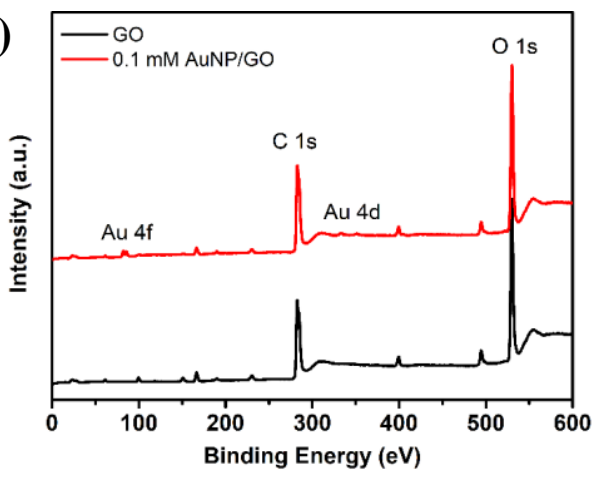

(C)

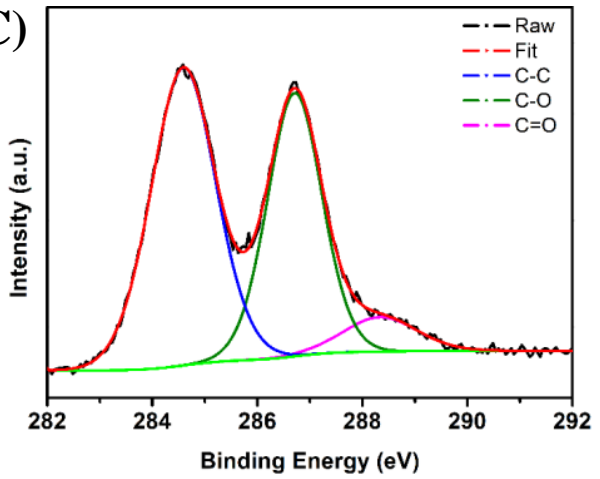

(B)

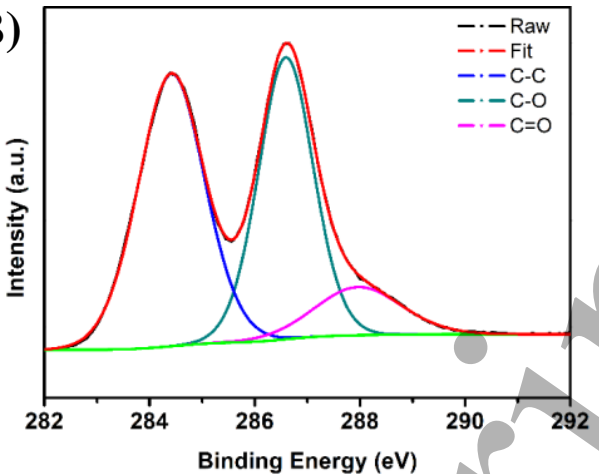

(D)

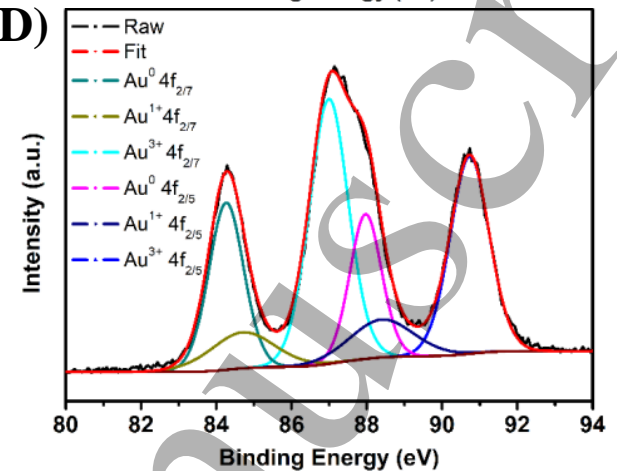

(E)

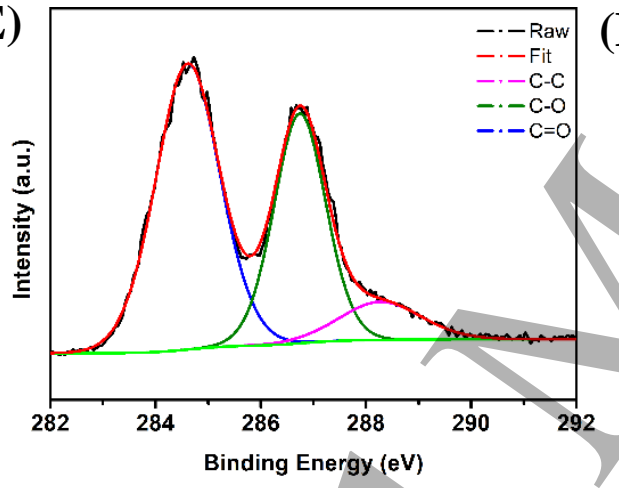

(F)

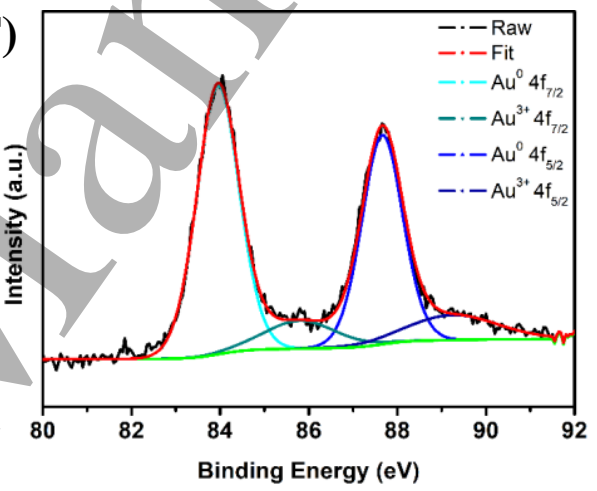

Figure 4. (a) survey XPS spectra of GO and $0.1 \mathrm{mM} \mathrm{AuNP/GO;} \mathrm{(b)} \mathrm{C} \mathrm{1s} \mathrm{core} \mathrm{peak} \mathrm{of} \mathrm{GO;} \mathrm{(c)} \mathrm{and} \mathrm{(d)} \mathrm{C} \mathrm{1s} \mathrm{and}$ $\mathrm{Au} 4 \mathrm{f}$ core peak of $0.1 \mathrm{mM} \mathrm{HAuCl} / \mathrm{GO}$; (d)-(e) $\mathrm{C} 1 \mathrm{~s}$ and $\mathrm{Au} 4 \mathrm{f}$ core peak of $0.1 \mathrm{mM}$ AuNP/GO.

1 through significant change during APM treatment. These results indicate the efficient reduction of gold 2 precursor and formation of AuNP due to the APM treatment. In contrast to APM assisted synthesis of 3 AuNPs only, the formation of AuNPs in the present work can be influenced by both the APM induced Table 2. C 1s core peak analysis results for GO, $0.1 \mathrm{mM} \mathrm{HAuCl}_{4} / \mathrm{GO}$ mixture and $0.1 \mathrm{mM}$ AuNP/GO nanocomposites.

\begin{tabular}{|c|c|c|c|c|c|c|c|}
\hline \multirow{2}{*}{ Samples } & & \multicolumn{3}{|c|}{ Carbon species } & \multicolumn{3}{|c|}{$\mathrm{Au}$ species } \\
\hline & & $\mathrm{C}-\mathrm{C}$ & $\mathrm{C}-\mathrm{O}$ & $\mathrm{C}=\mathrm{O}$ & $\mathrm{Au}^{1+}$ & $\mathrm{Au}^{3+}$ & $\mathrm{Au}^{0}$ \\
\hline & $\mathrm{BE}(\mathrm{eV})$ & 284.4 & 286.6 & 288.0 & -- & -- & -- \\
\hline & Fraction (\%) & 47.9 & 41.0 & 11.1 & -- & -- & -- \\
\hline & $\mathrm{BE}(\mathrm{eV})$ & 284.6 & 286.7 & 288.3 & $84.7 / 88.4$ & $87.0 / 90.7$ & $84.2 / 87.9$ \\
\hline$=4$ & Fraction (\%) & 52.9 & 40.3 & 7.0 & 14.3 & 53.3 & 31.4 \\
\hline & $\mathrm{BE}(\mathrm{eV})$ & 284.6 & 286.7 & 288.3 & $84.9 / 88.8$ & -- & $84.0 / 87.7$ \\
\hline (2) & Fraction (\%) & 55.1 & 35.6 & 9.3 & 25.2 & -- & 74.8 \\
\hline
\end{tabular}




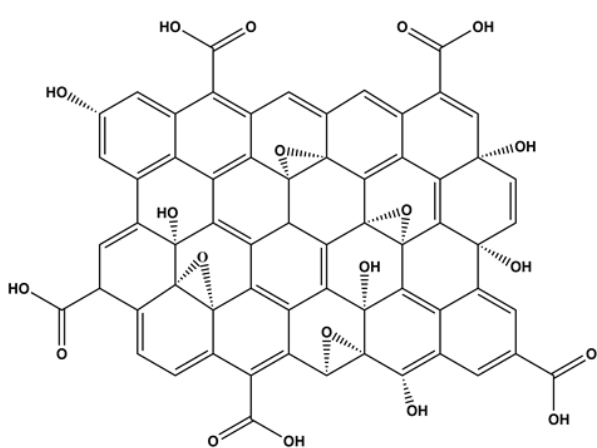

$\mathrm{GO}$

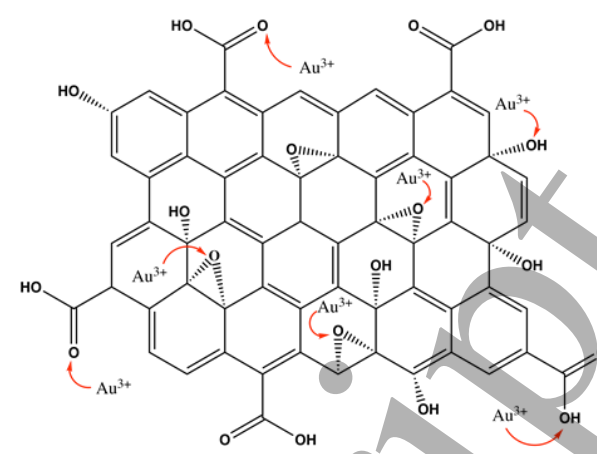

$\mathrm{HAuCl}_{4} / \mathrm{GO}$ mixture

Scheme 2. The schematic of electrostatic interactions between $\mathrm{Au}^{3+}$ and oxygen-functionalities on the surface of GO

1 rich liquid chemistry and the presence of GO. When the $\mathrm{HAuCl}_{4}$ was mixed with $\mathrm{GO}$ solution, the GO

2 surface functional groups (- $\mathrm{COOH}$, or $\mathrm{O}-\mathrm{C}-\mathrm{O}$ ) will first interact with $\mathrm{AuCl}_{4}$ ions through electrostatic

3 interaction, as is shown by scheme 2[34]. Apart from the XPS analysis earlier, this interaction can also

4 be evidenced by the UV-Vis spectra shown in Figure 5. The GO band ( $230 \mathrm{~nm})$ in the UV-Vis spectrum

5 disappeared from the $0.1 \mathrm{mM} \mathrm{HAuCl} / \mathrm{GO}$ aqueous mixture sample. Instead, a boarder $\mathrm{AuCl}_{4}{ }^{-}$band

6 emerged at $216 \mathrm{~nm}$, indicating the interfacial interaction between $\mathrm{GO}$ and $\mathrm{HAuCl}_{4}$. The formation

7 mechanism of AuNP/GO nanocomposites as a result of APM treatment has been illustrated in Scheme

8 3. The solvated electrons $\left(\mathrm{R}_{I}\right.$ in Scheme 3$)$ and $\mathrm{H}_{2} \mathrm{O}_{2}\left(\mathrm{R}_{I I}\right.$ in Scheme 3$)$ are believed to be the two main

9 species that trigger the initial reduction of the gold precursors $[5,8,9,55,56]$. When the mixture was

10 subject to APM treatment, the $\mathrm{AuCl}_{4}{ }^{-}$ions anchored on the $\mathrm{GO}$ surface and any unbound free $\mathrm{AuCl}_{4}^{-}$

11 ions in the bulk solution were reduced into free $\mathrm{Au}^{0}$ atoms through both $\mathrm{R}_{\mathrm{I}}$ and $\mathrm{R}_{\mathrm{II}}$ reaction pathways

12 (Step 1 in Scheme 3). The associated half-cell reactions for $R_{I}$ and $R_{I I}$ are:

13

$$
\mathrm{Au}^{3+}+3 \mathrm{e}^{-} \rightarrow \mathrm{Au}^{0}
$$

$$
\mathrm{Au}^{3+}+\mathrm{OH}^{-}+3 \mathrm{H}_{2} \mathrm{O}_{2} \rightarrow \mathrm{Au}^{0}+3 \mathrm{H}_{2} \mathrm{O}+3 \mathrm{HO}_{2}
$$

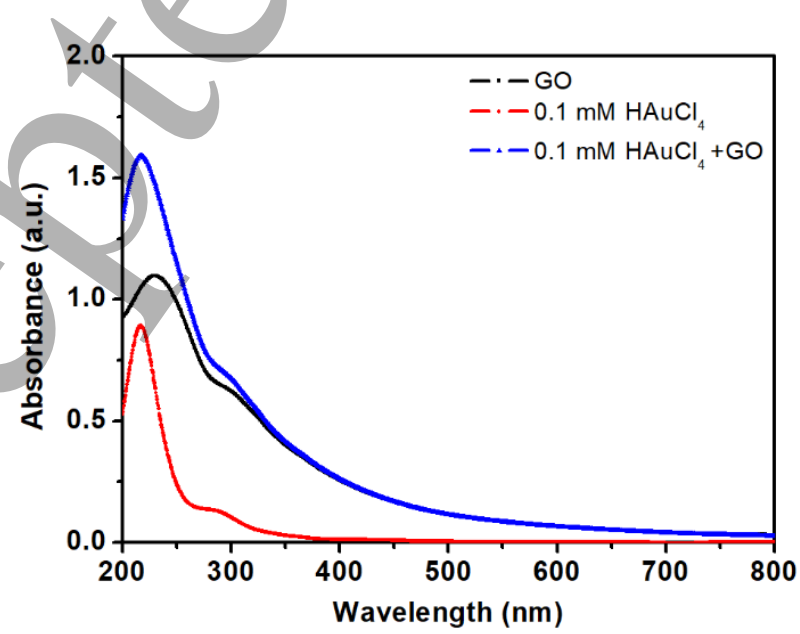

Figure 5. The UV-vis spectra of GO, $0.1 \mathrm{mM} \mathrm{HAuCl}_{4}$ and $0.1 \mathrm{mM} \mathrm{HAuCl} / 4 \mathrm{GO}$. 


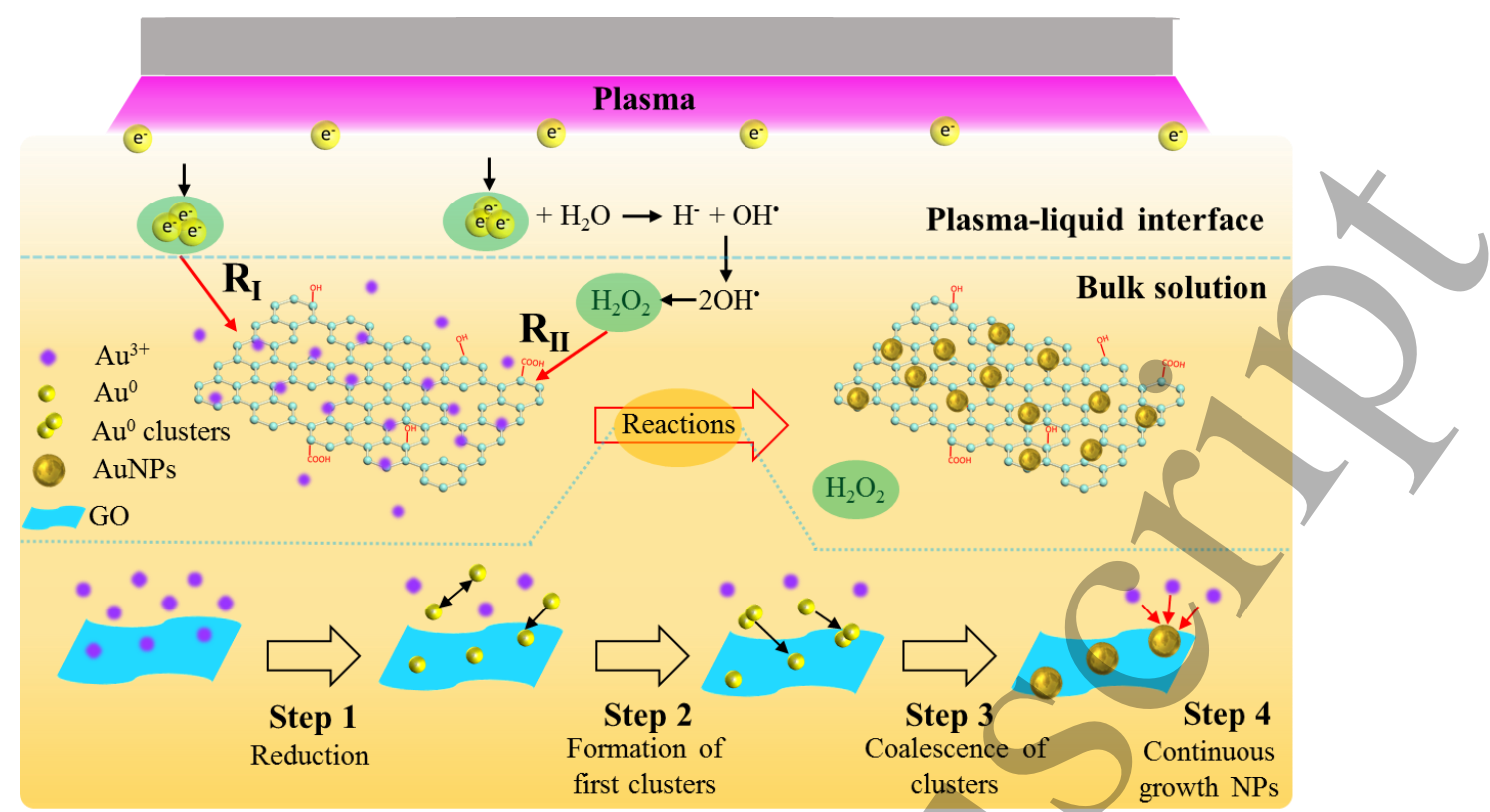

Scheme 3. Formation mechanism of AuNP/GO under the physical and chemical processes induced by APM.

1 It is worth pointing out that the reduction induced by the short-lived solvated electrons (Eq. 1) is usually 2 constrained at the plasma-liquid interfaces[9,56], while the ability of $\mathrm{H}_{2} \mathrm{O}_{2}$ to diffuse into the bulk 3 solution enable the reduction of the remaining gold precursors ( $\mathrm{AuCl}_{4}^{-}$) (Eq. 2). The APM induced 4 nucleation and subsequent NP growth in the present study is very much similar to the process seen in 5 conventional wet chemistry; however, due to the APM induced reduction steps, the supply of the Au 6 monomer is kinetically driven by the APM induced reaction products. That is, the initial growth of Au 7 clusters is through the coalescence of Au atomic nuclei, and the subsequent growth of AuNPs arise 8 from the coalescence of Au clusters at the cost of reduction in the number of clusters/NPs[57,58]. In 9 the presence of GO, on the other hand, the formation of first $\mathrm{Au}^{0}$ clusters can take place on the $\mathrm{Au}-\mathrm{O}$ $10 \mathrm{C}$ bonding sites on the $\mathrm{GO}$ surface (or also in the bulk solution, depending on the $\mathrm{HAuCl}_{4}$ precursor/GO ratio) (Step 2). The as-formed $\mathrm{Au}^{0}$ clusters further coalesce with others clusters to form stable seed AuNPs (Step 3). In the event where residual Au ions are still present in the solution after Step 3, the ions will be attracted towards the seed AuNPs due to the presence of their surface electric double layer (EDL) and the $\mathrm{H}_{2} \mathrm{O}_{2}$ within the bulk liquid will further reduce these ions into $\mathrm{Au}^{0}$ as part of the continuous surface growth process (Step 4) $[8,58,59]$. The AuNPs formed in the bulk solution could also be physically adsorbed onto the GO surface through the interactions between GO aromatic structures and d-orbitals of AuNPs via covalent attachment[40]. It should be noticed that the formation and growth of AuNPs will cease when $\mathrm{AuCl}_{4}{ }^{-}$ions within the precursor solution are depleted. For instance, in the $2.5 \mu \mathrm{M} \mathrm{HAuCl}_{4} / \mathrm{GO}$ sample, the further growth of AuNP after the initial formation of Au clusters was not possible, due to the rapid depletion of $\mathrm{AuCl}_{4}{ }^{-}$ions at low precursor concentration. 21 Whereas for $0.1 \mathrm{mM}$ and $0.2 \mathrm{mM}$ AuNP/GO nanocomposites, there is more abundant supply of $\mathrm{AuCl}_{4}^{-}$ 22 in the solution to sustain the growth of AuNPs until they reach their colloid stability. It should be noted 


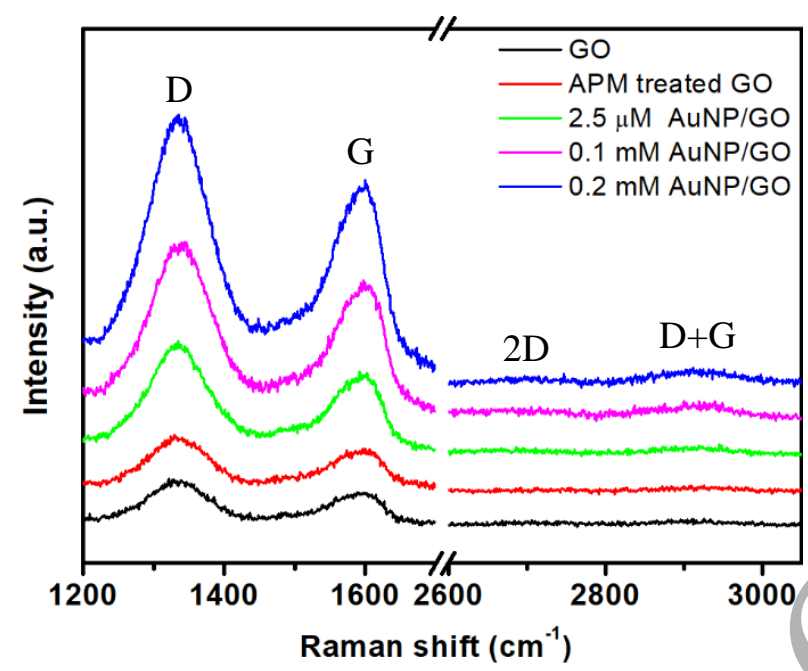

Figure 6. Raman spectra of GO, APM treated GO, and AuNP/GO nanocomposites.

1 that the morphology of the AuNPs can also be affected by the density and chemical nature of oxygenated

2 groups on the GO surface[40].

3 The Raman scattering properties of our AuNP/GO nanocomposites have been investigated with pure

4 GO and APM treated GO being the references, see Figure 6. All samples feature a typical disordered

5 band ( $\mathrm{D}$ band at $1330 \mathrm{~cm}^{-1}$ ) which represents the $\mathrm{A}_{\mathrm{gg}}$ mode $\mathrm{sp}^{2}$ hybridized carbon atoms in defects; and

6 a typical graphene-like band $\left(\mathrm{G}\right.$ band at $\left.1596 \mathrm{~cm}^{-1}\right)$ which relates to the $\mathrm{E}_{2 \mathrm{~g}}$ mode $\mathrm{sp}^{3}$-like carbon

7 atoms.[60] The $\mathrm{D} / \mathrm{G}$ intensity ratio $\left(\mathrm{I}_{\mathrm{D}} / \mathrm{I}_{\mathrm{G}}\right)$ of $\mathrm{APM}$ treated $\mathrm{GO}$ increased to 1.07 , as compared to 1.04

8 for pure GO. The slight increase in the $\mathrm{I}_{\mathrm{D}} / \mathrm{I}_{\mathrm{G}}$ ratio indicates that the APM treatment altered the structure

9 of GO, due to the reduction of oxygen-containing groups. [61] Compared to pure GO and APM treated

$10 \mathrm{GO}, \mathrm{AuNP} / \mathrm{GO}$ samples exhibit significantly stronger SERS at the D band and G band, and the intensity 11 of the 2D peak $\left(\sim 2680 \mathrm{~cm}^{-1}\right)$ and the $\mathrm{D}+\mathrm{G}$ peak $\left(\sim 2911 \mathrm{~cm}^{-1}\right)$ have also been enhanced. The 12 enhancements of these Raman peaks can be attributed to the SPR oscillations of electrons on AuNPs 13 under laser irradiation. Additionally, it is observed that the Raman signal intensifies for samples 14 prepared from higher $\mathrm{HAuCl}_{4}$ precursor concentrations. This can be related to the AuNPs size within 15 the nanocomposites, as larger AuNPs normally possess higher SERS efficiency[16].

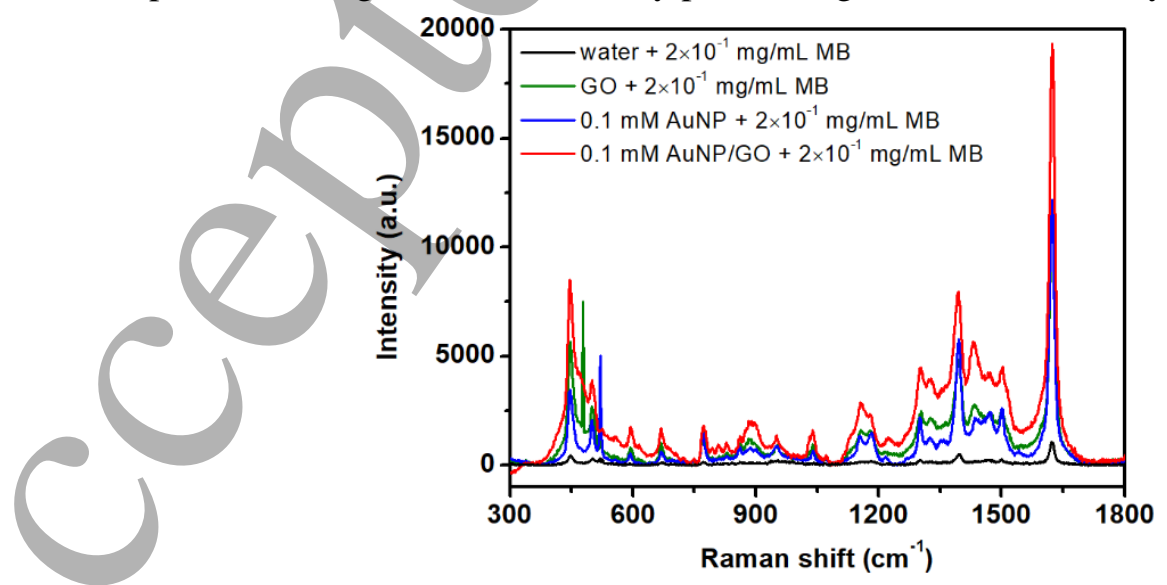

Figure 7, Raman spectra of GO, $0.1 \mathrm{mM}$ AuNP, and $0.1 \mathrm{mM}$ AuNP/GO for $2 \times 10^{-1} \mathrm{mg} / \mathrm{mL}$ MB sensing; Pure MB was used as reference. 
1 To evaluate the feasibility of our APM synthesized AuNP/GO nanocomposites for potential SERS bio2 sensing, a commonly used aromatic molecule MB was chosen as a model probe[62,63]. Figure 7 3 presents the Raman scattering spectrum of MB only (control) and the SERS spectra of MB on pure GO, $4 \quad 0.1 \mathrm{mM}$ AuNP, and $0.1 \mathrm{mM}$ AuNP/GO nanocomposites, respectively. It is noticed that the Raman signal 5 (based on the characteristic band at $1625 \mathrm{~cm}^{-1}$ ) of MB is negligible in the MB only sample. When GO 6 or $0.1 \mathrm{mM}$ AuNP were used as SERS substrates, the MB SERS signals are intensified significantly. The 7 enhancement seen in these two samples is due to the charge transfer between MB and the substrate via 8 two different SERS enhancement mechanisms: (i) CM due to the $\pi-\pi$ stacking between MB and GO, 9 and (ii) EM due to the electrostatic interaction between MB and AuNPs[30,64,65]. When $0.1 \mathrm{mM}$ $10 \mathrm{AuNP} / \mathrm{GO}$ was used as the SERS substrate, the signal was further enhanced, due to the combined effects 11 of CM and EM. In order to quantitatively determine the SERS sensitivity of our AuNP/GO nanocomposites, MB solutions with different concentrations were tested. Figure 8 shows that the Raman signal of MB only sample can be hardly detected when the concentration is lower than $1 \times 10^{-1}$ $\mathrm{mg} / \mathrm{mL}$. However, the use of $0.1 \mathrm{mM}$ AuNP/GO significantly enhanced the characteristic peak signal $\left(1625 \mathrm{~cm}^{-1}\right)$ and the detection limit can reach as low as $1 \times 10^{-3} \mathrm{mg} / \mathrm{mL}$.

16 The biocompatibility of SERS substrate material is of particular importance for bio-related SERS 17 applications[66]. In this work, the cytotoxicity of 0.1 mM AuNP/GO was evaluated in vitro using HeLa cell using alamarBlue ${ }^{\mathrm{TM}}$ cell viability Assay. The cytotoxicity of the pure GO and the $0.1 \mathrm{mM}$ AuNP were used as reference. Results show that all samples are highly biocompatible after incubation of $24 \mathrm{~h}$ (Fig 9A), $48 \mathrm{~h}$ (Fig 9B), and $72 \mathrm{~h}$ (Fig 9C). Both GO and $0.1 \mathrm{mM} \mathrm{AuNP/GO}$ show comparable
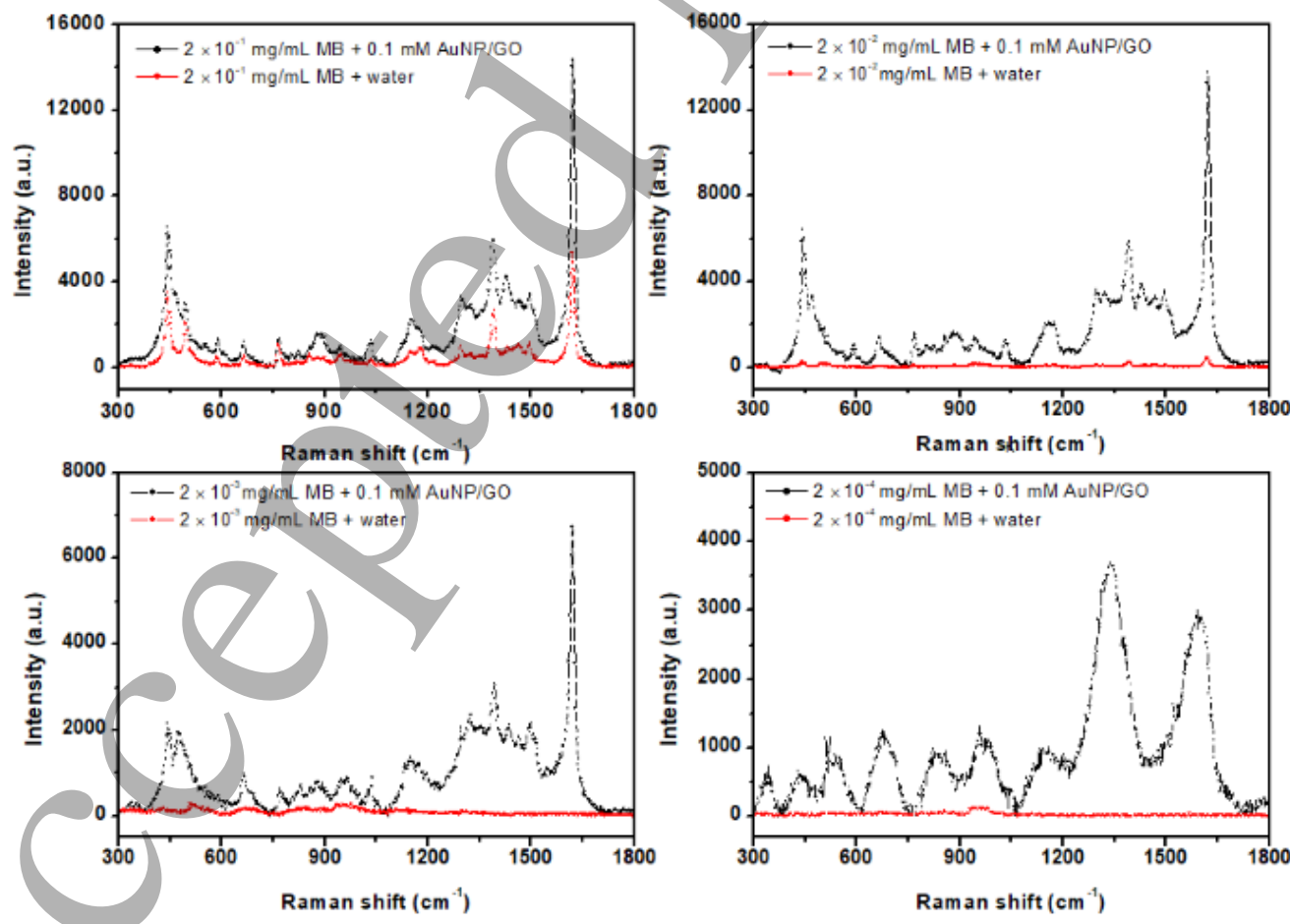

Figure 8. Raman spectra of $0.1 \mathrm{mM}$ AuNP/GO for sensing MB with different concentrations. 

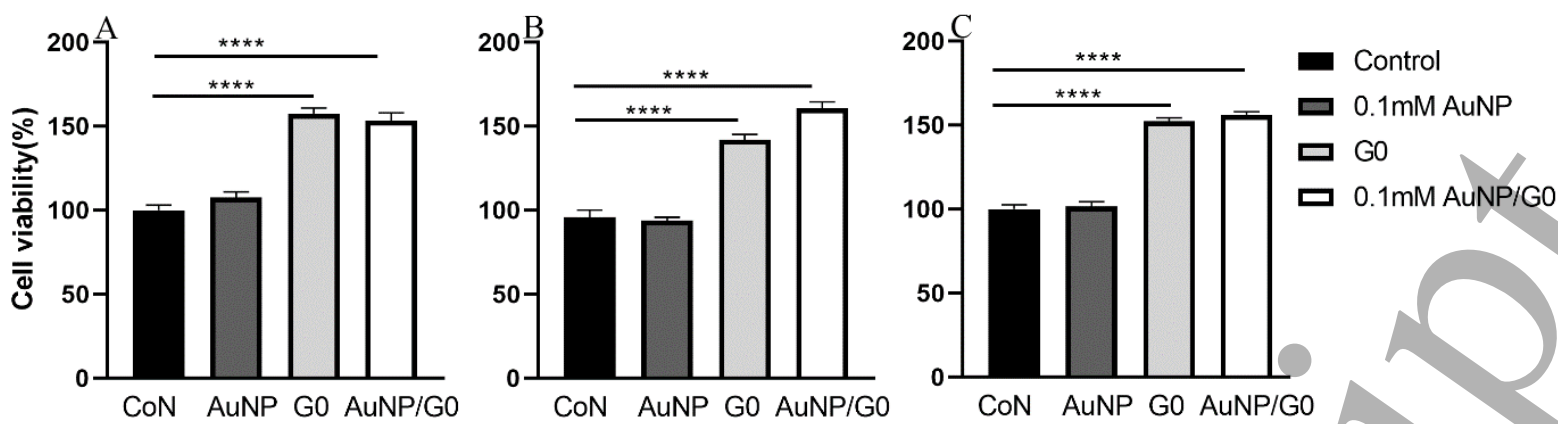

Figure 9. Cell viability of HeLa cell was measured by alamarBlueTM® cell viability Assay after incubated with pure GO, $0.1 \mathrm{mM}$ AuNP and 0.1 mM AuNP/GO for $24 \mathrm{~h} \mathrm{(A),} \mathrm{48h} \mathrm{(B),} \mathrm{and} 72 \mathrm{~h}(\mathrm{C})$, respectively. Data were presented as mean $\pm \mathrm{S}, \mathrm{E}$, and $\mathrm{N}=5$. One way ANOVA followed by Dunnett's multiple comparisons test. **** $\mathrm{p}<0.0001$.

1 biocompatibility, as well as ability to further enhance the cell proliferation comparing to the $0.1 \mathrm{mM}$

2 AuNP sample. These preliminary results demonstrate that our AuNP/GO nanocomposites are highly

3 biocompatible and may be considered for biosensing applications and beyond.

4 Conclusion

5 In summary, we demonstrated a rapid and facile single step APM based approach for synthesizing

6 AuNP/GO nanocomposites. The reactive species generated through APM-liquid interaction are

7 responsible for the formation of the AuNP-GO nanocomposites within the complicated multi-phase

8 reaction system consisting of gas, liquid and solid nanomaterials. The as-synthesized AuNP/GO

9 nanocomposites exhibited excellent biocompatibility and has been demonstrated for SERS sensing

10 applications where high detection sensitivity (probe molecule concentration as low as $1 \times 10^{-3} \mathrm{mg} / \mathrm{mL}$ )

11 has been achieved.

12

13

14

15

16

17

18

19

20

21

22

\section{Acknowledgments}

The authors would like to acknowledge the Engineering and Physical Sciences Research Council (EPSRC) for funding support (EP/P00394X/1 and EP/M015211/1). This research has also been supported from the European Union's Horizon 2020 research and innovation programme under the Marie Skłodowska-Curie grant agreement No 722717 (OCUTHER). Daye Sun thanks the China Scholarship Council (CSC) for the financial support.

Reference

[1] Mariotti D and Sankaran R M 2010 J. Phys. D. Appl. Phys. 43323001

[2] McKenna J, Patel J, Mitra S, Soin N, Švrček V, Maguire P and Mariotti D 2011 Eur. Phys. J. Appl. Phys. 5624020

[3] Mariotti D, Patel J, Nemcova L, Maguire P, W G Grahamand and D Mariotti 2012 Plasma Process. Polym. 9 1074-85 
[4] Bruggeman P J, Kushner M J, Locke B R, Gardeniers J G E, Graham W G, Graves D B, Hofman-Caris R C H M, Maric D, Reid J P, Ceriani E, Fernandez Rivas D, Foster J E, Garrick S C, Gorbanev Y, Hamaguchi S, Iza F, Jablonowski H, Klimova E, Kolb J, Krcma F, Lukes P, MacHala Z, Marinov I, Mariotti D, Mededovic Thagard S, Minakata D, Neyts E C, Pawlat J, Petrovic Z L, Pflieger R, Reuter S, Schram D C, Schröter S, Shiraiwa M, Tarabová B, Tsai P A, Verlet J R R, Von Woedtke T, Wilson K R, Yasui K and Zvereva G 2016 Plasma Sources Sci. Technol. 25053002

[5] Bratescu M A, Cho S P, Takai O and Saito N 2011 J. Phys. Chem. C 115 24569-76

[6] Huang X Z, Zhong X X, Lu Y, Li Y S, Rider a E, Furman S a and Ostrikov K 2013 Nanotechnology 24095604

[7] Du C and Xiao M 2014 Sci. Rep. 47339

[8] Patel J, Němcová L, Maguire P, Graham W G and Mariotți D 2013 Nanotechnology 24 245604

[9] Maguire P, Rutherford D, Macias-Montero M, Mahony C, Kelsey C, Tweedie M, PérezMartin F, McQuaid H, Diver D and Mariotti D 2017 Nano Lett. 17 1336-43

[10] Ni C, Carolan D, Rocks C, Hui J, Fang Z, Padmanaban D B, Ni J, Xie D, Maguire P, Irvine J T S and Mariotti D 2018 Green Chem. 202101

[11] Wang R, Zuo S, Zhu W, Zhang J and Fang J 2014 Plasma Process. Polym. 11 448-54

[12] Yan T, Zhong X, Rider a E, Lu Y, Furman S a and Ostrikov K K 2014 Chem. Commun. 50 3144-7

[13] Zhang R C, Sun D, Zhang R, Lin W F, Macias-Montero M, Patel J, Askari S, McDonald C, Mariotti D and Maguire P 2017 Sci. Rep. 746682

[14] Nolan H, Sun D, Falzon B G, Maguire P, Mariotti D, Zhang L and Sun D 2019 Plasma Process. Polym. 161800128

[15] Nolan H, Sun D, Falzon B G, Chakrabarti S, Padmanaba D B, Maguire P, Mariotti D, Yu T, Jones D, Andrews G and Sun D 2018 Plasma Process. Polym. 151800112

[16] Sun D, McLaughlan J, Zhang L, Falzon B G, Mariotti D, Maguire P and Sun D 2019 Langmuir DOI: 10.1021/acs.langmuir.8b03945

[17] Zhu Y, Murali S, Cai W, Li X, Suk J W, Potts J R and Ruoff R S 2010 Adv. Mater. 22 39063924

31 [18] He M, Chen X, Guo Z, Qiu X, Yang Y, Su C, Jiang N, Li Y, Sun D and Zhang L 2019 Comp. 
Sci. Tech. 174 194-201

[19] Chen C, Sun X, Pan W, Hou Y, Liu R, Jiang X and Zhang L 2018 ACS Sustain. Chem. Eng. 6 $3862-3869$

[20] Ma X, Qu Q, Zhao Y, Luo Z, Zhao Y, Ng K W and Zhao Y 2013 J. Mater. Chem. B 1, 64956500

[21] Saravanan S, Sareen N, Abu-El-Rub E, Ashour H, Sequiera G L, Ammar H I, Gopinath Y, Shamaa A, Sayed E, Moudgil M, Vadivelu J and Dhingra S 2018 Sci. Rep. 815069

[22] Liu J, Ma Q, Huang Z, Liu G and Zhang H 2018 Adv. Mater. 311800696

[23] Turcheniuk K, Boukherroub R and Szunerits S 2015 J. Mater. Chem. B 3 4301-24

[24] Jensen L, Aikens C M and Schatz G C 2008 Chem. Soc. Rev. 37 1061-1073

[25] Yu X, Cai H, Zhang W, Li X, Pan N, Luo Y, Wang X and Hou J G 2011 ACS Nano 5 952958

[26] Wang P, Liang O, Zhang W, Schroeder T and Xie Y H 2013 Adv. Mater. 25 4918-4924

[27] Tao Y, Lin Y, Huang Z, Ren J and Qu X 2013 Adv. Mater. 25 2594-2599

[28] Huang J, Zong C, Shen H, Liu M, Chen B, Ren B and Zhang Z 2012 Small 8 2577-84

[29] Lu G, Li H, Liusman C, Yin Z, Wu S and Zhang H 2011 Chem. Sci. 2 1817-1821

[30] Fu W L, Zhen S J and Huang C Z 2013 Analyst 138, 3075-3081

[31] Hu C, Rong J, Cui J, Yang Y, Yang L, Wang Y and Liu Y 2013 Carbon 51 255-264

[32] Wang Q, Li Q, Yang X, Wang K, Du S, Zhang H and Nie Y 2016 Biosens. Bioelectron. 77 1001-1007

[33] Iliut M, Leordean C, Canpean V, Teodorescu C M and Astilean S 2013 J. Mater. Chem. C 1 4094-4104

[34] Goncalves G, Marques P A A P, Granadeiro C M, Nogueira H I S, Singh M K and Grácio J 2009 Chem. Mater. 21 4796-802

[35] Li Y, Yang J, Zhou Y, Zhao N, Zeng W and Wang W 2017 Colloids Surfaces A Physicochem. Eng. Asp. 512 93-100

[36] Li Y, Yang J, Zhou Y Z, Zhong T, Zheng S H and Zeng W W 2016 Monatshefte fur Chemie $147677-683$ 
[37] Huang J, Zhang L, Chen B, Ji N, Chen F, Zhang Y and Zhang Z 2010 Nanoscale 2 2733-2738

[38] Fan Z, Kanchanapally R and Ray P C 2013 J. Phys. Chem. Lett. 4 3813-3818

Hu Y, Lu L, Liu J and Chen W 2012 J. Mater. Chem. 22 11994-12000

Hernández-Sánchez D, Villabona-Leal G, Saucedo-Orozco I, Bracamonte V, Pérez E, Bittencourt C and Quintana M 2018 Phys. Chem. Chem. Phys. 20 1685-1692

Matsumura Y and Ananthaswamy H N 2004 Toxicol. Appl. Pharmacol. 195 298-308.

Haiss W, Thanh N T K, Aveyard J and Fernig D G 2007 Anal. Chem. 79 4215-21

3cAllister M J, Li J L, Adamson D H, Schniepp H C, Abdala A A, Liu J, Herrera-Alonso M, Milius D L, Car R, Prud'homme R K and Aksay I A 2007 Chem. Mater. 19 4396-4404

[44] Huang H H, De Silva K K H, Kumara G R A and Yoshimura M 2018 Sci. Rep. 86849

[45] Li C C, Chen L B, Li Q H and Wang T H 2012 CrystEngComm. 14 7549-7551

[46] Evans J E, Jungjohann K L, Browning N D and Arslan I 2011 Nano Lett. 11 2809-2813

[47] Cheong S, Watt J D and Tilley R D 2010 Nanoscale 2, 2045-2053

[48] Otari S V., Kumar M, Anwar M Z, Thorat N D, Patel S K S, Lee D, Lee J H, Lee J K, Kang Y C and Zhang L 2017 Sci. Rep. 710980

[49] Yang E, Chou H, Tsumura S and Nagatsu M 2016 J. Phys. D. Appl. Phys. 49185304

[50] Minicò S, Scirè S, Crisafulli C and Galvagno S 2001 Appl. Catal. B Environ. 34 277-285

[51] Goguet A, Ace M, Saih Y, Sa J, Kavanagh J and Hardacre C 2009 Chem. Commun. 0 48894891

[52] Boyen H G, Kästle G, Weigl F, Koslowski B, Dietrich C, Ziemann P, Spatz J P, Riethmüller S, Hartmann C, Möller M, Schmid G, Garnier M G and Oelhafen P 2002 Science 297 1533-6

[53] Zhang N, Qiu H, Liu Y, Wang W, Li Y, Wang X and Gao J 2011 J. Mater. Chem. 21 1108011083

[54] Li X R, Li X L, Xu M C, Xu J J and Chen H Y 2014 J. Mater. Chem. A 2 1697-1703

[55] Yan T, Zhong X, Rider A E, Lu Y, Furman S A and Ostrikov K 2014 Chem. Commun. 50 $3144-7$

[56] Rumbach P, Bartels D M, Sankaran R M and Go D B 2015 Nat. Commun. 67248

28 [57] Polte J, Erler R, Thünemann A F, Sokolov S, Ahner T T, Rademann K, Emmerling F and 
$1 \quad$ Kraehnert R 2010 ACS Nano 4 1076-1082

2 [58] Polte J 2015 CrystEngComm. 17 6809-6830

3 [59] Wuithschick M, Birnbaum A, Witte S, Sztucki M, Vainio U, Pinna N, Rademann K,

4 Emmerling F, Kraehnert R and Polte J 2015 ACS Nano 9 7052-71

5 [60] Malard L M, Pimenta M A, Dresselhaus G and Dresselhaus M S 2009 Phys. Rep. $47351-87$

6 [61] Moon I K, Lee J, Ruoff R S and Lee H 2010 Reduced graphene oxide by chemical graphitization. 2010 Nat. Commun. 1 73-79

8 [62] Yilmaz M, Babur E, Ozdemir M, Gieseking R L, Dede Y, Tamer U, Schatz G C, Facchetti A, Usta H and Demirel G 2017 Nat. Mater. 16 918-924

[63] Reguera J, Langer J, Jiménez De Aberasturi D and Liz-Marzán L M 2017 Chem. Soc. Rev. 46 3866-3885

[64] Hao Q, Wang B, Bossard J A, Kiraly B, Zeng Y, Chiang I K, Jensen L, Werner D H and Huang T J 2012 J. Phys. Chem. C 116 7249-7254

[65] Huh S, Park J, Kim Y S, Kim K S, Hong B H and Nam J M 2011 U ACS Nano 5 9799-9806 